\title{
The Prophetic approach and methodology towards the cultural and civilizational impact on education
}

\author{
Dr. Abdul Fareed Brohi ${ }^{*}$
}

\begin{abstract}
:
The Prophet Muhammad (peace be upon him) preached the message of Islam in Arabia, which later on spread in almost all the continents, Muslims interacted with the adherents of different religions and civilizations. There are many instances and models from the life of the Prophet which guides us to understand the prophetic approach and methodology towards education and character building. These encounters and models include the migration, battles, treaties and dialogues within and without. In human history, the cultures and civilizations are compelled to relate to one another on a continuous and constant basis. The main theme of this study and research is to focus on the Prophetic approach and methodology towards education. The researcher tried to seek the answers of the issues of today's world which are being faced by the world in general and the Muslim Ummah in particular related to education. The study will sort out the guidelines which could be found in the Life of the Prophet and the attitude and Hikmah (wisdom) of the Prophet towards education seeking a Prophetic approach for the contemporary phenomenon of cultural and civilizational pluralism. What would the Prophet (peace be upon him) do nowadays in the modern world and what Sunnah teaches the Ummah regarding and solving these issues? This paper is an attempt to answer these questions.
\end{abstract}

Keywords: Islam, Prophet, methodology, civilization, knowledge, west, learning

\section{Introduction:}

Islam is the religion of peace and coherence revealed to the Prophet Muhammad (peace be upon him) as a true guidance and mercy for the mankind. When the Prophet migrated to Madinah; one of the basic institutions which he established in the early days, was the institution of Mosque. Masjid-e-Nabavi was the center of all the activities of the newly

\footnotetext{
* Assistant Professor, International Islamic University, Islamabad. abdul.fareed@iiu.edu.pk
} 
established state of Madinah. It became the center of education and learning. This was the beginning of the establishment of an ideology, which is the Islamic Ideology. The Islamic ideology is considered to be the ideology of the Islamic education system. That needs such an educational system where faith would be the basis of the Islamic civilizational approach. In human history, the cultures and civilizations are compelled to relate to one another on a continuous and constant basis. It is very evident from the history of Islam that when the message of Islam was being spread all over the world, Muslims integrated with other cultures and civilizations of the known world. Very soon, the era of Islamic knowledge began. Muslims were not only becoming the conquerors of new borders outside the Arabia, instead they were in the forefront in conquering knowledge through research, explorations and translations. After the conquest of Persia and Rome, the then centers of power and knowledge, the Muslims integrated with the Persian, Roman and later on Greek civilizations. They get involved into translating the master pieces of philosophical works of Greek knowledge. But it is known fact that by the passage of time, after a long rule, the Muslim world declined. In the period of colonization, and at the verge of the Ottoman Caliphate, a large area of the Muslim world came under the influence of the West. In the twentieth century, many Muslim states established after a long struggle for freedom. Pakistan came into being on 14th of August 1947 in the name of Islam. The Muslims of India, being a separate nation, wanted a piece of land where they could live according to their distinct culture, history, and way of life, religion, literature and social values. Allama Muhammad Iqbal gave the concept of Pakistan, a road map of a separate homeland for the Muslims of subcontinent. Under the enthusiastic leadership of Quaid-e-Azam Muhammad Ali Jinnah Pakistan became the reality on the map of the world. From the very beginning of its existence, Islam has been the ideology of Pakistan. That ideology is the Islamic ideology. When Samuel Huntington presented the idea of the 'Clash of Civilizations', it was meant by the Islamic civilization and the Islamic Ideology. It is the ongoing history which is witnessing the clash between different ideologies and civilizations.

Prophet Muhammad (peace be upon him) is the role model in guiding to combat the present cultural and civilization scenario and invasion. History witnessed that the Prophet of Islam, changed the attitude of the illiterate people of the Arabian Peninsula into a more civilized and mannered society. It was the beginning of a new era and civilization. The Ummah under the enthusiastic leadership of the Prophet, entered into the era of knowledge. Prophethood not only is the source of detailed laws of Shariah but it is the basic source of al-Ilm (The Knowledge). It is the blessings of 
Prophethood that it provides the basic knowledge to humanity which leads to the great central reality. This knowledge is worthwhile as it has basic realities of life and guiding principles and permanent moral values. If Prophet Muhammad (peace be upon him) is there, no other source or guide is required.

The Islamic worldview revolves around the concept of the 'Oneness of God', the role of 'Man' and the 'Universe'. The Islamic ideology develops through the troika of these basic concepts. The concept of the 'Oneness of God' is the foremost foundation of Islamic ideology. The universe itself invokes man to look into the creation of man himself and the creation of all the heavens and earth. What is al-Ilm (the Knowledge)? What are its objectives and what is the wisdom of the Prophet which guides the Muslims in the cultural and civilizational era today? In the next lines the researcher tries to reveal the guidelines which could be found in the Life of the Prophet and the attitude and Hikmah (wisdom) of the Prophet towards education seeking a Prophetic approach for encountering the contemporary phenomenon of cultural and civilizational pluralism. The Western concept of knowledge only addresses the facts which could be comprehended through human intellect.

\section{Dar-e-Arqam: The first Center of Knowledge}

The first revelation was Iqra, $\operatorname{Read}^{2}$. It shows the stress on seeking education and knowledge by the All Mighty Lord, Allah. It is very known history of the Sirah and Islam that the Prophet started the preaching of Islam after getting command from Allah. When a few people accepted his message, the first step he took in Makkah, was the establishment of a center for the Muslims, where they could be able to seek and learn knowledge from the Holy Prophet (peace be upon him). Dar-e-Arqam became the first center of knowledge for the Muslims ${ }^{3}$. At Dar-e-Arqam, the methodology of the Prophet was to first recite the revealed verses of the Quran to his companions ${ }^{4}$. After that he used to give them directions about Islam. Initially, most of the education was oral and verbal. The early method was not formal in its nature and character.

Another way to preserve the revelation was done by the scribes. The Prophet ordered some of his companions to listen the verses of the Quran then they wrote it down. Paper was rare at that time, so they preserve it on parchments, on leaves of date tree, on bones of camels and on leather ${ }^{5}$.

\section{Migration to Madinah:}

In the 13th year of Prophethood, Muhammad (peace be upon him) migrated to Madinah with his companion, Abu Bakr. At the time of 
Hijrah, it was very strange that while he was being chased by his enemies, there was material for writing in his bag, like pen, ink and paper ${ }^{6}$. Suraqah ibn Malik, one of the Bedouins, was also chasing them. When he came closer to them, the legs of his horse sank in the sand three times which was odd to him as his horse never did this before. Suraqah begged the Prophet for peace. So the Prophet gave him the promise of protection in writing ${ }^{7}$. This is a very strange and very peculiar from the life of the Prophet. After the Hijra and reaching at Madinah, the Prophet took three major steps ${ }^{8}$ :

- Establishment of a center for the newly established community of Muslims; the Masjid-e-Nabawi.

- Brotherhood among the Muslims.

- Pacts with the Muslims of Madinah and with the tribes of Jews.

Mosque being the center of the Muslim Ummah, became the central part of society, culture and civilization. Mosque was not mere a place of worship rather it was a center of solving the issues and matters of the members of the society. Today, in the modern world, while combatting with the cultural and civilizational attacks, Mosque could be a place where we can take refuge.

\section{Suffah: The Platform of Knowledge}

Suffah, a platform where the weak and homeless companions used to stay at and to learn from the Prophet directly. It was built in the rear side of Masjid-e-Nabawi ${ }^{9}$. As Dr Hamidullah named it the first ever university of Islam $^{10}$. A residential house of learning where the Prophet himself was the mentor and teacher. Abu Hurairah was one of the examples of Ashab-eSuffah ${ }^{11}$.

\section{The Prophet's Methodology of Teaching:}

The Prophet usually sat in the Mosque after Fajr prayer with his companions $^{12}$. Here I would like to present an example just for a better understanding of the method of education. When we look into the history and compilation of Quran, it becomes evident that Quran was not compiled completely in the life time of the Prophet. It was completely compiled later in the caliphate of Abu Bakr. So is the case of other sciences like Quranic Sciences, Hadith Sciences and so on. Education is also like that. In the early days of the Madinah state, there was no formal education as we observe nowadays like schools and Madaris. Rather it was the initial stage of schooling. The Prophet after the Morning Prayer (Fajr), used to sit in the mosque and asked questions from his companions. Usually he listened the dreams of the people who had that dreams at night. 
The Prophet interpreted the dreams. At sometimes the Prophet delivered a small sermon. Those companions who were not present at the occasion, they inquired from those who were present. In today's world everyone emphasizes on seeking every kind of knowledge, but the Prophet of Islam very elaborately directed to seek that knowledge which is beneficial for humanity and for the nation. It was one of the important methods of teaching which the Prophet adopted along with emphasizing on education. He taught the companions to get Ilm Nafeh (Beneficial Knowledge). The Prophet used to recite the following supplication:

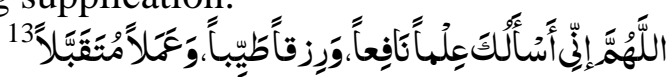

"O Allah, I ask You for knowledge that is benefit, a good provision, and deeds that will be accepted."

It shows that the knowledge which does not has any benefit is of no use. In the following lines, some more methods of teaching are being given for a better understanding of the Prophetic methodology. The Prophet very clearly communicated his message to the audience as proper communication is the very basic tool. The Prophet of Islam not only talked with a clear voice so everyone could hear it but sometimes he used to repeat a sentence thrice or twice. It helps everyone to comprehend the message very easily. On some occasions the Prophet tried to invoke the curiosity of his companions by asking questions. Sometimes he tried to divert the concentration of people by giving some examples. The Messenger of Allah, Peace and mercy be upon him said: "Every one of you (people) is a shepherd. And every one is responsible for whatever falls under his responsibility. A man is like a shepherd of his own family, and he is responsible for them." ${ }^{14}$ This Hadith is reported by both Bukhari and Muslim. He addressed the people according to their level and mentality. He asked his companions to make things easy for people. The Prophet of Islam says:

"Give glad tidings, and do not scare people away. Make things easy, and do not make things difficult." 15

Muhammad (peace be upon him) is the Prophet of hope. So he tried to keep people in the circle of Islam rather to make them run away.

What would Muhammad (peace be upon him) do nowadays? One very important aspect of the Prophet gives a lesson about gaining and benefiting knowledge. The Battle of $B a d r$ was the first major clash between the forces of Islam and forces of disbelief. The Muslims won the battle of Badr which was fought in the first year of the Hijrah ${ }^{16}$. In this battle the Muslims proceeded to take the enemy soldiers as prisoners to Madinah. The ransom for the prisoners ranged between 4000 and 1000 
dirhams in accordance with the captive's financial situation. Another form of ransom assumed an educational dimension; most of the people of Makkah, unlike the people of Madinah, were literate and so each prisoner who could not afford the ransom was entrusted with ten children to teach them the art of writing and reading. Once the child had been proficient enough, the instructor would be set free. This act of the Prophet shows how much concerned the Prophet was about the promotion of knowledge. Another aspect of the life of the Prophet, was that he always been worried about learning and development of the newly converts. There were some of the companions of the Prophet who were the experts of Quran and they were also had interest in teaching. Among them were Abdullah bin Masood, Saalim Moala abi Huzaifa, Muaz ibne Jabal, and Ubbi bin Kaab. The Prophet handed the newly converts to these experts who taught them the basics of Islam and Quran.

Modern period is the era of Globalization. In modern times Globalization is a multi-faceted phenomenon which comprises all aspects of human life. Since the idea of globalization emerged and shaped in West, it was welcomed in most of the developing and third world countries. The concept of globalization was received with such delight because it offers these countries a great deal in terms of capital flow which promises them prosperity and affluence. After the Hijrah, the Prophet encountered with different tribes of Jews at Madinah. Many of the Jews spoke Hebrew as well. Many tribes other than them visited Madinah on different occasions to meet the Prophet and to have interaction with him. One of the scribes of the Prophet was Zaid ibne Thabit. The Prophet directed him to learn the Syriac language in which the Jews used to write. He said that he learnt that script. Zaid knew many other languages as well. This shows how the Prophet was concerned about learning. There is lesson for the Ummah in this era of globalization that learning the languages of other nations could be beneficial not only for the individual but also for the benefit of the Muslim community, the Muslim Ummah.

Along with seeking knowledge and learning how to read and write, the Prophet directed the members of the Muslim community to enhance their other abilities like archery, horse riding and swimming. In a hadith narrated from Hazrat Ibn Umar (R.A) in which our beloved Prophet said:

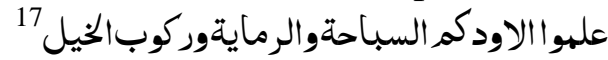

"Teach your children swimming, archery and horse riding."

In Sahih Muslim, the Prophet said, "Practice archery and horseback riding." ${ }^{18}$ The Prophet said "Any action without the remembrance of Allah is either a diversion or heedlessness except four acts: walking from target 
to target (during archery practice), training a horse and learning to swim." ${ }^{19}$ (reported by Tabarani). Here I would like to present a very interesting example from the life of the Prophet Muhammad (peace be upon him). Once the Prophet asked three of his young companions; Abdullah, Obaidullah and Kathir ibne Abbas, to stand in a row. Then the Prophet himself stood at a distance and asked them to reach him first. Three of the kids ran towards the Prophet (peace be upon him). They came near him and one of them climbed up the back of the Prophet, one hugged him. The Prophet (peace be upon him) caressed them, kissed and loved them. It was such a mode of race.

To combat with the challenges of the cross culture civilization, Sirah of the Prophet also guides us in firming the unit of the family as well. Family is the basic and core unit of a society which has a significant role. Parents and children are the key players of that unit. As much this unit becomes stronger, the society will become more functional, active and vibrant. Every member of this unit has its own role and contribution which makes it more and more successful. The role of good parenting and how the children raised, has a direct effect for the capacity building of the family unit to effect positive social change. The family not only transforms its members but ultimately society as a whole. It's a matter of fact that good parenting matters and how the style of parenting we adopt as our choice, affects the kind of people our children become. Strong parent-child relation revolves around love, care, peace and security. A loving family responds to both the needs of the parents as well as the needs of the children. Nowadays it has been observed that not only the western societies facing the issues like single-parent families, divorce, changes in family size and instability; the Muslim families and the Islamic world is also facing these instabilities. The developing societies cannot exist without healthy family units, and this is also true for the Muslim world. It's the need of time to make it sure to strengthen this unit because a family is part of the larger culture and ideally, a whole culture itself. We should understand the role of the greatness of the roles we play within the family. A family is a little house of worship, a little government, and a little place of learning of positive values and goodness ${ }^{20}$.

As mentioned above this is the era of Globalization. The Golden Age of Muslims and Islam (750-1260) is now history. Although Muslims were in the forefront in conquering knowledge through expeditions, explorations, scientific study and research. They integrated with different cultures and civilizations. The early Muslim scholars engaged and used the approach of adapt, adopt, assimilate and integrate. One can observe the expansion of Muslim's scholarly works in the West which are now preserved in the 
educational institutions of the West. By the 15th and 16th century of the Common Era, West became dominant through its expeditions and especially colonialism. This was the time of the fall of Muslim Rule. The Muslims were declining and the West was raising through its technology and in the field of science. Colonization made Muslim countries very much dependent on the Western colonial powers. Although many of the Muslim states liberated, but their dependency has given the Western world an advantage in maintaining their control over their former colonies. Colonization in the modern period is no longer physical in nature, but the minds and souls of the developing and third world countries are under the control of disguised or 'Psychological' colonization. Penetration of the West in Muslim world is very evident as they brought their language, culture, system of administration, and the more influential the system of education. These things give the Western world giving their hegemony over the countries which are under their influence.

In the Western world, knowledge has been sought for achieving a good wealthy life. Though it is not wrong to seek knowledge for material gains, but it may not have been the solely purpose of seeking knowledge. The cultural and civilizational invasion has brought Western culture and way of life to the Islamic world and to rest of the world. Secularism which is the basis of the Western world is being translated to the Islamic world. It has its own values which are atheistic in its nature that do not support the Supremacy of Allah the Almighty Lord. The ultimate result of this invasion is secularism. On the other hand, the main aim and objective of education in Islam is to seek the pleasure of Allah. In Islam, knowledge is sought for the betterment and improvement of self. It makes a man humble and makes him accountable to his Creator. Knowledge is sought for the development of man that brings him closer to his God. Islam calls on the Muslims to take a stand by being judgmental. One has to be clear in his mind as to what are the things that have been permitted or rejected by Quran and Sunnah with regards to the human relationship. By referring to the Islamic guidelines, one can easily differentiate between what is good and allowed and what is bad and should be shunned.

\section{The Prophetic Approach:}

Knowledge or al-Ilm, is regarded as the 'Inheritance of the Prophets. al$I l m$, as narrated by Aby Huraira, is that knowledge which is sought for the pleasure of Allah $^{21}$. The core of 'the Knowledge' is to attain the 'Reassured Soul'(Nafs-ul-Mutmainnah). When we seek guidance from the life of the Prophet Muhammad (peace be upon him) in terms of knowledge and education and in combating the cultural and civilizational invasion, it 
become more and more clear that al-Ilm is the foundation of all the Uloom or sciences. It has to be the central point around which all the educational system and curriculum depends. Muhammad (peace be upon him) was the leader in all aspects of life and we can say he was also the leader of an extraordinary movement of education. He himself said that "I have been sent as a teacher." 22 The wisdom and the position of Muhammad (peace be upon him) is above all the humanity with regard to education. The message of Islam spread all over the world with the wisdom and mission of the Prophet of Islam.

\section{What Would Muhammad (peace be upon him) Do?}

The whole society was like a classroom for him. The opinion of the educationist becoming very clear that in today's world even any kind of change will come from class room. In the next few lines we shall see the wisdom and strategy of Muhammad (peace be upon him) and his methodology about education step wise. These lines will also point out the answer of the main research question; i.e. what would Muhammad (peace be upon him) do? Quran very clearly mentions the role and the purpose of his Prophethood. In Surah Al Imran Allah says:

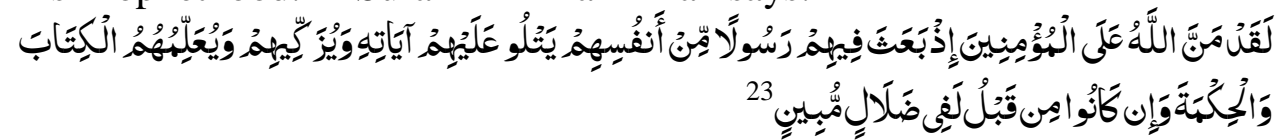

"Surely Allah conferred a great favour on the believers when He raised from among them a Messenger to recite to them His signs, and to purify them, and to teach them the Book and Wisdom. For before that they were in manifest error."

Here four main roles of the Prophet mentioned categorically. First to recite the Quran, second to purify the souls of the Muslim community, third to teach them the book and finally to teach them wisdom(Hikmah). Among these qualities and objectives of prophethood, one of the main role of the Prophet Muhammad (peace be upon him) is to teach. Quran mentions his duties that his responsibility is to deliver the message of God to the people clearly.

"...then your duty is merely to deliver the message."

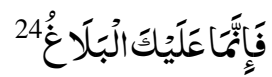
This had been the duty of every Prophet. Quran says about that:

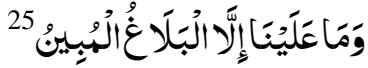

"And our duty is no more than to clearly convey the Message."

One of the methodology which was adopted by the Prophet Muhammad (peace be upon him) was to be lenient towards people. Quran mentions it 
as under:

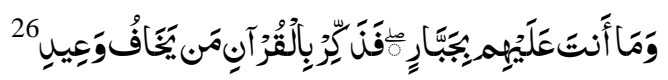

"And you are not required to force things on them. So exhort with the Quran all those who fear My warning"

This is the required quality which has to be adopted in today's world by every person especially the leaders of Muslim Ummah.

\section{Conclusion:}

The wisdom which was taught to the Prophet was to be patience and to provide easiness.

$$
\text { وعن أنسرضى اللهعنه النبى صلى اللهعليهوسلمقال: “يسرواولاتعسرواوبشرواولاتنفروا }
$$

The Prophet (peace be upon him) said, "Make things easy and do not make them difficult, cheer the people up by conveying glad tidings to them and do not repulse (them)."

The aim and objective about education and educating people was very much clear to the Prophet. It was to prepare people who would deliver the message of Islam. The Sirah of the Prophet is the role model for all the humanity. During his life as a prophet, Muhammad (peace be upon him) spend 13 years of his life in Makkah and 10 years in Madinah. He spent his life according to the guidance from God which was revealed to him gradually over a period of twenty-three years. These were the methods which he then taught to others. The Prophet used a diversity of teaching methods to train his companions, such as telling stories and making gestures to demonstrate his point. In one instance, the Prophet said, "I and the person who looks after an orphan and provides for him, will be in Paradise like this," putting his index and middle fingers together ${ }^{27}$. Another methodology was to draw simple explicit graphics or illustrations to deliver some of his intellectual thoughts and concepts. These methods and methodologies are also applicable in today's world towards the cultural and civilizational impact on education.

The Prophetic methodologies are like a teaching manual for how to conduct one's life. He put much emphasis on seeking knowledge and its proper application. He took the opportunity to teach the foundations of Islam, using methods that were appropriate to the situation, and likewise encouraged his followers and companions to act upon the teachings of Quran and Sunnah. The Prophet used many strategies for communicating and spreading the divine message. He used to make drawings and used gestures while explaining anything. He asked questions, told stories and used parables to lead his companions to the conclusion, rather than imparting information without discussion. The Prophet was known for 
adapting the lesson to the needs and mental level of the audience. Prophet Muhammad (peace be upon him) encouraged his followers to think, to observe and to be responsible. On many occasions the Prophet used his method of correcting bad behavior by giving examples, which helped his companions remember what they were taught. The Prophet spoke in a very easy and understandable manner. Because of this, his companions were able to memorize many of his teachings. Mother of the Believers, Aisha, said that he "used to speak so clearly that if somebody wanted to count the number of his words, he could do so." 28 This was repeated by many other scholars, whose comments include, "Allah's Messenger never talked so quickly and vaguely as you do" 29 and he spoke distinctly so that all those who listened to him, understood him. The message of the Prophet Muhammad (peace be upon him) is our guide in the present situation.

\section{References:}

${ }^{1}$ Samuel P. Huntington, The Clash of Civilizations and the Remaking of World Order, 1996, p.27

${ }^{2}$ Al-Quran. Surah Al-Alaq verse 1

${ }^{3}$ Safiur Rahman Mubarakpuri, Ar-Raheeq Al-Makhtum, p.96

${ }^{4}$ Muhammad Hamidullah, Khutbat-e-Bahawalpur, p.37

${ }^{5}$ Ibid.

${ }^{6}$ Ibid.

${ }^{7}$ Shibli Nomani, Siratun Nabi, Vol. I. p.205

${ }^{8}$ Ibid.

${ }^{9}$ Ibid.

${ }^{10}$ Khutbat p.56

${ }^{11}$ Siratun Nabi, Vol. I. p.207

12 Ibid.

${ }^{13}$ Muhammad bin Yazid Ibn Majah, Sunnan Ibn Majah, Vol.1, Book 5, Hadith 925

${ }^{14}$ Muhammad bin Ismail Bukhari, Sahih al Bukhari, Book 10, Hadith 1

${ }^{15}$ Ibid. Book 73, Hadith 146

${ }^{16}$ Siratun Nabi, Vol. I. p.215

${ }^{17}$ Imam Ahmed Bin Hanbal, Musnad Ahmad, Vol. 1 p.46

${ }^{18}$ Imam Muslim Ibn Al-Hajjaj, Sahih al Muslim, Sahih Abi Dawood 2236

19 Tabarani

${ }^{20}$ Parent Child Relation, p.24

${ }^{21}$ Mishkat

${ }^{22}$ Muhammad bin Yazid Ibn Majah, Sunnan Ibn Majah Vol. 1, Book 1, Hadith 229

${ }^{23}$ Al-Quran, Surah Al-Imran verse 164

${ }^{24}$ Ibid., Surah Ar-Ra'd verse 40

${ }^{25}$ Ibid., Surah Yaseen verse 17

${ }^{26}$ Ibid., Surah Qaf verse 45

${ }^{27}$ Muhammad bin Ismail Bukhari, Sahih al-Bukhari, Book 78, Hadith 36

${ }^{28}$ Ibid., Book 56, Hadith 768

${ }^{29}$ Ibid. 